\title{
中国茶の含水率と水分活性
}

\author{
農研機構果樹茶業研究部門* \\ 池田奈実子 ${ }^{\dagger}$ \\ 静岡県工業技術研究所** \\ 渡瀬 隆也
}

(平成28年 9 月 16 日受理)

\section{Moisture Contents and Water Activities in Chinese Tea}

\author{
Namiko Ikeda \\ NARO Institute of Fruit Tree and Tea Science \\ Takaya Watase \\ Industrial Research Institute of Shizuoka Prefecture
}

\begin{abstract}
Summary
Most of tea produced and consumed in Japan is steamed green tea. However, various tea types for domestic demand are needed to increase of tea consumption in Japan. Moisture contents and water activities are important for the maintenance of tea quality during storage. It has been shown that the optimum moisture content of Japanese green tea is 3-5\%. On the other hand, the moisture content of black tea is about $7 \%$, but the quality does not deteriorate during storage. It is thought that the optimum moisture contents of other types of tea are higher than that of Japanese green tea. Since there are many types of Chinese tea, useful information might be obtained from investigation of the moisture contents and water activities in Chinese tea. Difference between tea types was significant at the $1 \%$ level for moisture content in Chinese tea. The average moisture contents of white tea and dark tea were higher than those of blue tea, green tea and black tea. Difference between countries was significant at the $1 \%$ level for moisture contents in black tea. The moisture content of black tea from China was higher than the moisture contents of black tea from Nepal, Japan and India. The variance among moisture contents of blue tea was large. There were significant positive correlations between moisture contents and water activities in blue tea, green tea, black tea and dark tea. For teas with higher moisture contents, such as over $10 \%$, the water activity in dark tea was lower than those in other types of tea. Since water activities in almost all of the Chinese teas were less than 0.65 , it was assumed that no microorganisms can grow in Chinese tea.
\end{abstract}

Key Words : Camellia sinensis, Chinese tea, moisture content, water activity

キーワード：中国茶，含水率，水分活性

* $\quad \bar{T} 428-8501$ 静岡県島田市金谷猪土居2769

** $\quad$ T421-1298 静岡市葵区牧ケ谷2078

Corresponding author : namiko@affrc.go.jp 


\section{1 緒 言}

現在, 我が国で生産される茶のほとんどは蒸し製緑茶 であるが，1960年代までは輸出品として，紅茶などもつ くられていた。1958年にJapan Export Trade Promotion Agencyから発行された冊子「Japan Tea」では, 煎茶 の含水率の基準が5.5\%であるのに対して, 紅茶の含水 率の基準は $7.0 \%$ と記載されている ${ }^{1)}$ 。また, 1950年, 1951年の月刊誌「茶」には全国製茶品評会の入賞茶に ついて，住所，氏名，審査得点とともに含水率が記載 されている。1950年の入賞茶では, 煎茶の含水率の平 均值は $4.3 \%$ であるが, 紅茶の含水率の平均值は $8.0 \%$ で ある ${ }^{2)} 。 1951$ 年の入賞茶では, 煎茶の含水率の平均值は $4.2 \%$ であるが, 紅茶の含水率の平均值は $6.6 \%$ である ${ }^{3)}$ 。 当時は冷蔵や窒素充填などの包装技術が実用化されてお らず，輸送や保存中の劣化を防ぐ方法として，含水率の 制御が重要であったと考えられる。ところが，1971年の 紅茶輸入自由化によって日本における紅茶の商業生産は 壊滅し, 公的機関における紅茶に関する試験研究や普及 指導は中止された。半世紀近い空白によって, 生産者, 研究機関, 行政機関とも技術や知識の伝承が不十分であ る。紅茶の含水率についても，最近出版された本に「紅 茶の適正な含水率は3.5〜 $5 \%$ と書かれているが ${ }^{4}$ ，現 状とは異なっている ${ }^{5)}$ 。

近年，日本の茶生産は蒸し製緑茶がほとんどであった が，少しずつ他の茶種の生産が増加している。まず，機 能性ドリンクの原料として導入された紅茶用品種 ‘べに ふうき’の使われなくなった原料が，紅茶や半発酵茶に 転用されている ${ }^{6)}$ 。また, 二番茶, 三番茶価格が低迷し ている状況で7)，付加価值を付けるために ‘やぶきた’ など緑茶用品種を利用した紅茶や半発酵茶の生産も少し ずつ増加している。さらに, 微生物制御発酵茶のような 新たな茶の生産も行われるようになった ${ }^{8)}$ 。茶需要の減 少 $^{9)}$ を食い止めるためには, 様々な需要に対応できる ように，国内で生産する茶について，茶種の幅をさらに 広げる必要があると考えられる。

著者は現在の日本産及び外国産紅茶の含水率について 測定し, 日本，インド，スリランカ，ネパール産の紅茶 の含水率は産地に関係なく $7 \%$ 前後であること, またオ ーソドックス製法の紅茶の含水率はCTC製法の紅茶の 含水率より高いことを明らかにした ${ }^{5)}$ 。日本の緑茶の貯 蔵に最適な含水率は $5 \%$ 前後であることが明らかにされ ているが ${ }^{10)}$ ，貯蔵中の変化をできるだけ少なくすること
が必要な日本の緑茶と異なり, 後熟が必要な茶種もある。 また，過度の乾燥によって，香りが失われる場合もある. 今後日本で生産される茶の種類が多様化した場合, 貯蔵 に最適な含水率は茶種によって異なると考えられる。

食品の保存には含水率だけではなく, 水の存在形態を 示す水分活性も重要である。食品中の水は自由水と結合 水の 2 種の状態で存在し, 自由水の割合を示す水分活性 值は微生物や酵素の働きや, 脂質酸化, 非酵素的褐変な どに影響を与える。一般には 0.65 以下ではすべての微生 物は繁殖できないとされている ${ }^{11)}$ 。茶でも保存性や後熟 に含水率だけでなく，水分活性が影響を与えていると考 えられるが, 茶の水分活性についての報告はみられない。 日本は再び茶の輸出を促進しているが, 輸出相手国の中 には，茶の貯蔵についての設備や知識が不十分な国もあ るため, 含水率の制御や水分活性值は輸送や貯蔵中の品 質低下を防止する手段として重要である。

人類が初めて茶を利用したのは中国で, 紀元前から嗜 好飲料の他, 薬用, 保健飲料, 食用として利用し, 製造 法や損取法も多様である ${ }^{12)}$ 。また, 茶はシルクロードの 時代から交易品であり, 流通や貯蔵に最適な含水率の制 御技術が経験的に蓄積されているため, 多様性に富んだ 中国茶の含水率を調べることによって, 茶の含水率及び 水分活性と保存中の変化との関係について知見を得るこ とができると考えられた。本報では, 中国産と台湾産の 中国茶について含水率と水分活性の測定を行い, 茶種間 の差異を明らかにした。また前報 ${ }^{5)} て ゙$ て明らかにした南 アジア及びアフリカの主要生産国の紅茶と中国紅茶の含 水率の差異を明らかにした。

\section{2 材料及び方法}

\section{1 含水率の測定}

2012年 9 月から2016年 4 月に, 中国産118点, 台湾産 56 点, 合計 174 点の茶を入手し, 試料として用いた。試 料の入手方法は, 中国及び台湾から招待を受けて訪問し た方からの分譲, FOODEXなどのイベントで入手, 台 湾茶の卸売り業者から購入, 中国及び台湾からの来所者 から寄贈など, 幅広いルートで入手した。大部分は上級 茶である。これらの中国茶は陳椽 ${ }^{12)}$ の分類にしたがっ て分類した（表 2 ）。紅茶の含水率の生産地による比較 では，前報 $(2013)^{5)}$ の試料も含めて，インド，スリ ランカ, ネパール, ケニア, トルコ, ジョージア, 日本 産の紅茶368点を用いた (表 4)。試料は入手直前まで未 開封で, 保存状態が良好で, 賞味できる状態のものを用 
いた。入手後すぐに測定を行った。試料として用いたの はすべてリーフティーで, ティーバッグは用いなかった。 含水率の測定は原（1990）の検討結果を参考にして行っ た ${ }^{13)}$ 。試料を粉砕せずに, 約 $5 \mathrm{~g}$ を秤量瓶に入れて, $105^{\circ} \mathrm{C}$ で48時間加熱し, 加熱前と加熱後の重量差から湿量基準 の含水率を求めた。平均值の多重比較検定は統計ソフト ウエアSTATISTICA '98 Editionを用いて行った。

\section{2 水分活性の測定}

水分活性の測定には表 6 の試料を用いた。水分活性 の測定装置は, ノバシーナ社水分活性測定装置LabMASTER-aw及びLab-Swift-awを用いた。直径 $38 \mathrm{~mm}$, 高さ $12 \mathrm{~mm}$ のプラスチック製の専用セルに充填して, 測 定装置のチャンバーに入れて測定を行った。

\section{3 結 果}

\section{1 中国茶の含水率}

中国茶174点を緑茶, 白茶, 青茶, 紅茶, 黒茶及び花 茶の 6 茶種に分類した。中国茶の含水率について, 茶種 を要因とする一元配置分散分析を行った。F検定の結果, $1 \%$ 水準で有意であり, 茶種間で含水率に差が認められ た（表 1$) 。$

\section{表 1 中国茶の茶種別の含水率に関する一元配置分散分析}

\begin{tabular}{cccc}
\hline 要因 & 自由度 & 平均平方 & $\mathrm{F}$ \\
\hline 茶種 & 5 & 62.57 & $13.58^{* *}$ \\
誤差 & 168 & 4.61 & \\
\hline
\end{tabular}

** : F検定の結果, $1 \%$ 水準で有意.

6 茶種の中で青茶の含水率は, 平均値は最も低かった が，ばらつきは最も大きかった。台湾の凍頂烏龍や阿里 山高山茶のような半球状の烏龍茶は，含水率が $5.0 \%$ 以 下のものが多かったが, 台湾の東方美人や中国の鳳凰単 叢の含水率は高く, $9.0 \%$ 以上のものも多かった。紅茶 は青茶より平均值が高く, $7.0 \%$ から $10.0 \%$ に多く分布し た。紅茶の含水率のばらつきは、青茶よりは小さかっ たが，白茶、黒茶よりは大きかった。白茶，黒茶は青 茶, 緑茶, 紅茶より含水率が高かった。黒茶の含水率は, 8.34\%から10.17\%で，ばらつきは小さかった（表 2, 図 $1)$ 。

紅茶368点の含水率について, 生産国を要因とする一 元配置分散分析を行った。F検定の結果， $1 \%$ 水準で有 意であり，生産国間で含水率に差が認められた（表 3$) 。$
表 2 中国茶の茶種別の含水率（\%）

\begin{tabular}{rcrrrrr}
\hline 茶種 & 試料数 & \multicolumn{2}{c}{ 平均値 } & 最高値 & 最小値 & \multicolumn{2}{c}{ 中間値 標準偏差 } \\
\hline 緑茶 & 17 & $7.09 \mathrm{ab}$ & 9.73 & 4.64 & 7.23 & 1.64 \\
白茶 & 17 & $10.30 \quad \mathrm{c}$ & 13.97 & 7.19 & 10.86 & 1.56 \\
青茶 & 77 & $6.73 \mathrm{a}$ & 11.69 & 2.24 & 6.40 & 2.59 \\
紅茶 & 45 & $8.38 \mathrm{~b}$ & 11.62 & 4.73 & 8.18 & 1.92 \\
黑茶 & 15 & $10.29 \mathrm{c}$ & 11.90 & 8.34 & 10.17 & 1.12 \\
花茶 & 3 & $8.75 \mathrm{abc}$ & 10.09 & 7.65 & 8.50 & 1.24 \\
\hline
\end{tabular}

Tukeyの多重比較検定の結果，平均值の異なる英文字間には $5 \%$ 水準で有意差あり。

中国産の紅茶の含水率の平均值は $8.73 \%$, 台湾産の紅茶 の含水率の平均值は $7.84 \%$ あ゙った。中国産の紅茶の含 水率は，ネパール産，日本産，インド産の紅茶の含水率 より高かった（表 4$)$ 。

表 3 生産国別の紅茶の含水率に関する一元配置分散分析

\begin{tabular}{lccc}
\hline 要因 & 自由度 & 平均平方 & $\mathrm{F}$ \\
\hline 生産国 & 8 & 19.30 & $5.41^{* * *}$ \\
誤差 & 359 & 3.57 & \\
\hline F検定の結果 & 1 \%水淮で有意 & &
\end{tabular}

表 4 生産国による紅茶の含水率（\%）の差異

\begin{tabular}{lclrrrr}
\hline \multicolumn{1}{c}{ 生産国 } & 試料数 & 平均值 & 最高值 & 最小值 & \multicolumn{2}{c}{ 中間值 標準偏差 } \\
\hline 中国 & 28 & $8.73 \mathrm{bcd}$ & 11.59 & 4.73 & 8.69 & 1.88 \\
台湾 & 20 & $7.84 \mathrm{a} \mathrm{c}$ & 11.62 & 4.89 & 7.72 & 1.96 \\
インド & 97 & $7.07 \mathrm{a}$ & 12.59 & 1.93 & 7.09 & 2.21 \\
スリランカ & 28 & $7.25 \mathrm{ab}$ & 10.94 & 4.48 & 7.09 & 1.55 \\
ネパール & 23 & $6.48 \mathrm{a}$ & 9.96 & 4.19 & 5.56 & 2.03 \\
ケニア & 6 & $7.28 \mathrm{ab}$ & 10.69 & 5.68 & 6.91 & 1.80 \\
トルコ & 4 & $7.08 \mathrm{ab}$ & 8.77 & 5.35 & 7.10 & 1.51 \\
ジョージ & 3 & $11.67 \mathrm{~d}$ & 12.11 & 11.01 & 11.88 & 0.58 \\
日本 & 159 & $6.99 \mathrm{a}$ & 12.76 & 3.08 & 7.06 & 1.73 \\
\hline
\end{tabular}

Tukeyの多重比較検定の結果，平均值の異なる英文字間には $5 \%$ 水準で有意差あり。

\section{2 中国茶の水分活性}

中国茶109点の水分活性について，茶種を要因とする 一元配置分散分析を行った。F検定の結果， 1 \%水準で 有意であり,茶種間で水分活性に差が認められた(表 5$)$ 。 白茶の水分活性の平均值は 0.58 で, 青茶, 紅茶より高か った。青茶は水分活性のばらつきが大きく, 白茶は水分 活性のばらつきが小さかった（表 6 ）。

表 5 中国茶の茶種別の水分活性に関する一元配置分散分析

\begin{tabular}{lccc}
\hline 要因 & 自由度 & 平均平方 & F検定 \\
\hline 茶種 & 5 & 0.07 & $5.27^{* * *}$ \\
誤差 & 103 & 0.01 & \\
\hline ** : F検定の結果, 1 \%水準で有意 &
\end{tabular}


表 6 中国茶の茶種別の水分活性

\begin{tabular}{ccccccc}
\hline 茶種 & 試料数 & 平均值 & 最高値 & 最小值 & 中間值 標準偏差 \\
\hline 緑茶 & 7 & $0.50 \mathrm{ab}$ & 0.59 & 0.41 & 0.51 & 0.07 \\
白茶 & 14 & $0.58 \mathrm{~b}$ & 0.63 & 0.47 & 0.60 & 0.05 \\
青茶 & 46 & $0.41 \mathrm{a}$ & 0.66 & 0.12 & 0.44 & 0.14 \\
紅茶 & 25 & $0.46 \mathrm{a}$ & 0.61 & 0.23 & 0.43 & 0.10 \\
黒茶 & 14 & $0.49 \mathrm{ab}$ & 0.60 & 0.28 & 0.51 & 0.08 \\
花茶 & 3 & $0.39 \mathrm{ab}$ & 0.57 & 0.23 & 0.38 & 0.17 \\
\hline
\end{tabular}

Tukeyの多重比較検定の結果，平均值の異なる英文字間には $5 \%$ 水準で有意差あり

\section{3 中国茶の含水率と水分活性の関係}

茶の含水率と水分活性の間の相関係数は, 青茶, 紅茶, 黒茶は $1 \%$ 水準で, 緑茶は $5 \%$ 水準で有意で, 正の相関関係が認められた。したがって，これらの 茶種では，含水率が多くなるほど，水分活性が高く なる傾向が認められた。白茶と花茶では, 含水率と 水分活性の間に正の相関関係は認められなかった。 白茶と黒茶は，含水率の大部分が $8.0 \%$ から $12.0 \%$ の 間に分布したが，水分活性は，白茶の大部分が 0.55 から0.65の間に分布したのに対して，黒茶は0.40か ら0.60に分布し，白茶より水分活性が低く，分布の 幅が大きかった。含水率が $8.0 \%$ 以上の紅茶は, 水 分活性が 0.40 前後のものもあったが，0.60前後のも のもあった。含水率が高い中国茶には水分活性が高 いものが多かった。最も水分活性が高かったのは, 青茶の鉄観音の $0.66 て ゙ ，$ 含水率は $11.58 \%$ であった。 しかしその他の試料の水分活性は 0.65 以下であった (図2)。
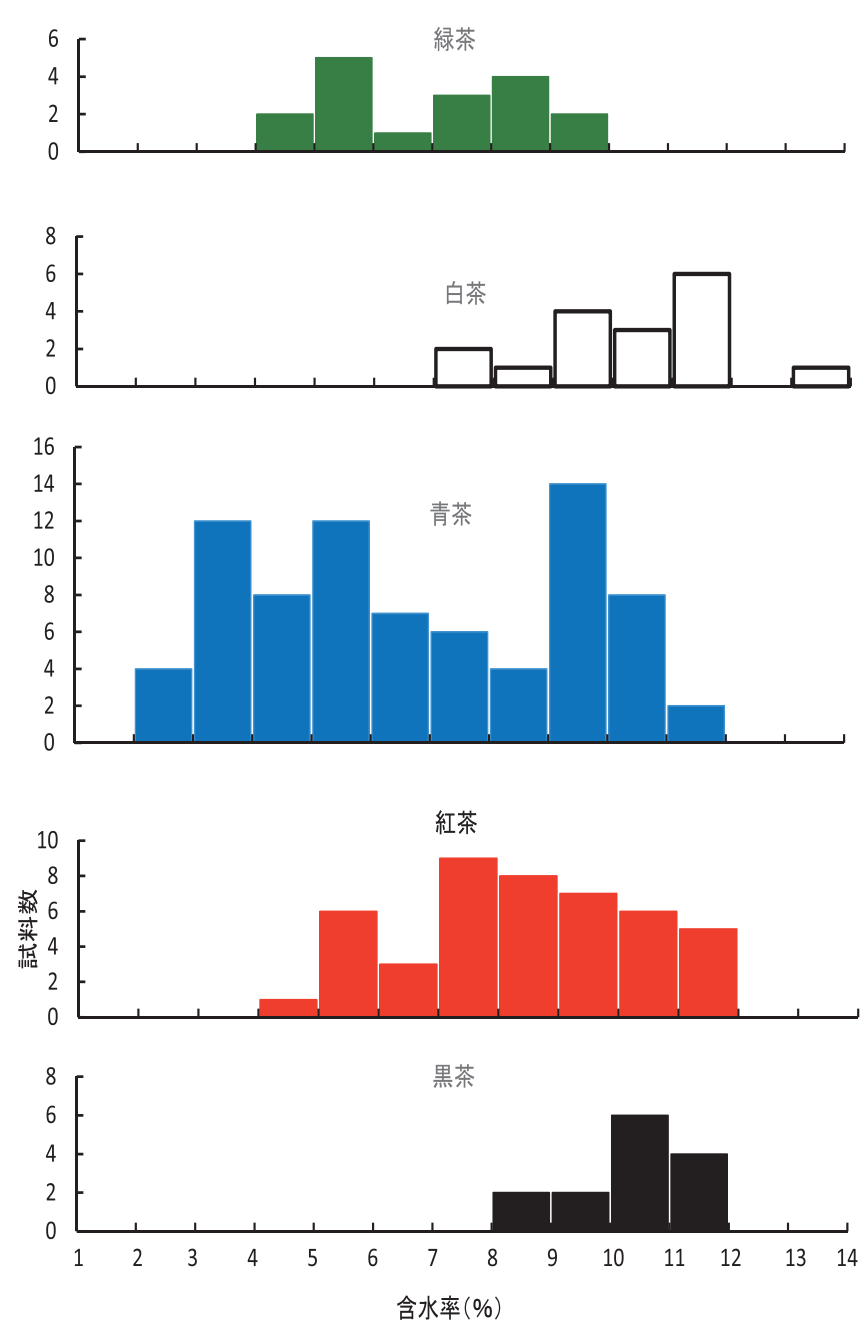

図 1 茶種別の中国茶の含水率の分布

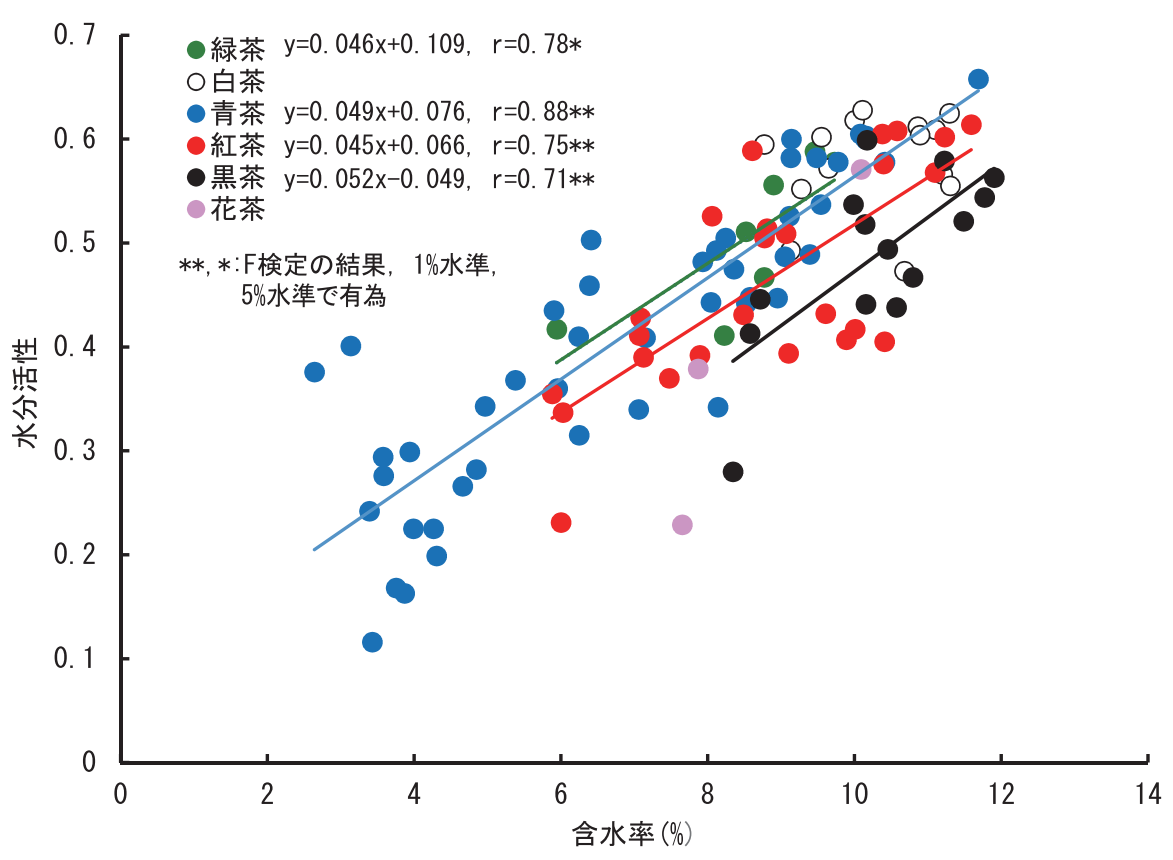

図 2 中国茶の茶種別の含水率と水分活性の関係 


\section{4 考 察}

前報において, 日本産緑茶の含水率は約 $5 \%$, インド, スリランカ, ネパール, 日本産紅茶の含水率は約 $7 \%$ で あることを報告したが5), 今回測定した中国茶の含水率 は，それらより高かった。また茶種によって差が認めら れた。

食品中の水のうち, 自由水は食品中の成分に束縛され ずに存在し，蒸発や水結にかかわり，移動する。結合水 は食品中の炭水化物やタンパク質の官能基との水素結合 によって結合して束縛された水で, 蒸発や水結が起こり にくく，物質を溶解したりすることができず，微生物の 繁殖や酵素反応には利用されない。水分活性は自由水の 割合を表し，ある一定の温度における食品の蒸気圧を純 水の蒸気圧で除した值で求められる ${ }^{11)}$ 。中国茶の含水率 と水分活性の関係は，一般的には含水率が高くなるほど 水分活性は高くなる傾向が認められた。しかし, 両者の 関係は茶種によって異なった。

中国産の緑茶の含水率は日本の緑茶より高かった。製 造後, 保管中の吸湿や流通段階での吸湿も考えられるが, 製造法の違いも含水率に影響していると考えられる。日 本の煎茶の製造工程では, 揉捻以外は加熱するため, それ ぞれの工程で水分が減少し, 乾燥直前の湿量基準の含水 率は10～12\%である ${ }^{14)}$ 。しかし, 中国緑茶の場合は, 乾燥 までは殺青しか加熱する工程がなく, 乾燥直前の含水率 が高いため, 乾燥だけでは含水率が低下しないと考えら れる。また中国緑茶は日本の煎茶のような乾燥しやすい 細長い針状ではなく，また煎茶より硬化した芽を使うこ とが多いことも, 水分が低下しにくい要因と考えられる。

青茶の含水率はばらつきが大きく, 半球状の包種茶は $6 \%$ 以下のものが多かった。青茶は中国, 台湾の広い地 域で生産が行われ，製法も様々である。半球状の包種茶 は揉捻工程で団揉と短時間の釜炒りを30回から40回以上 繰り返して成形を行うため, 他の製法に比べて水分が減 少すると考えられた ${ }^{15)}$ 。一方, 台湾産の東方美人や中国 産の鳳凰単叢の含水率が高いのは, 包揉のような少しず つ水分が減少する工程がなく, 殺青と乾燥でしか含水率 が低下しないからであると考えられた。

白茶の含水率は, 平均值が $10 \%$ を超えるような高いも のが多かった。インド・ニルギリのホワイトティーも他 の茶種に比べて含水率が高く, 同様の傾向であった ${ }^{16)}$ 。 白茶及びホワイトティーの製造工程は萎调後, 揉捻を行 わずに発酵止め, 乾燥を行う。したがって新芽の組織が
壊れないため水分が抜けにくく, 含水率が高いと考えら れた。

中国産の紅茶の含水率は, ネパール, 日本, インド産 の紅茶より高く，8\%以上であった。また台湾産の紅茶 の含水率の平均值も $7.84 \%$ であった。台湾 ${ }^{17)}$ や中国 ${ }^{18)} に$ おける紅茶製造では形状をよく締めてよることを重視し ている。そのためには萎调で水分を減らしすぎないこと が重要である。さらに江蘇省の宣興紅茶のように揉捻工 程の終了間際に揉捻盤へ加水を行っているものもある ${ }^{18)}$ 。 したがって, 乾燥直前の含水率が高いため, 乾燥後も水 分が多く残ると考えられた。

中華人民共和国国家基準及び地方の基準によって, 黒 茶の含水率の上限は種類によって異なるが 9.0 〜 $16.0 \%$ と 定められている ${ }^{19)}$ 。本試験の黒茶の含水率は 8.0 から 12.0 \%で，ほぼ基準以内であった。含水率が10\%を超えるよ うな試料では, 青茶, 白茶, 紅茶に比べて黒茶は相対的 に水分活性が低かった。同程度の含水率の時に他の茶種 と比べて黒茶の水分活性が低い要因については, 他の茶 種と異なって微生物による発酵工程が含まれることと, 貯蔵期間が長いことが関係していると考えられる。

南インドの紅茶用品種 ‘UPASHI-16’ の新芽からア セトンで抽出し，80\%硫酸アンモニウムを用いて分画さ れたポリフェノールオキシダーゼの活性は $70^{\circ} \mathrm{C} て ゙ 30$ 分保 った後も残存している ${ }^{20)}$ 。茶の後熟については科学的に ほとんど解明されていないが, 残存する酵素を利用した 反応であると考えられる。中国茶の適正な含水率は, 酵 素活性を利用でき, 微生物が繁殖しない水分活性となる ような範囲であると考えられる。茶の含水率が高過ぎる と微生物の繁殖が懸念される。茶種によって違いは見ら れるものの, 一般的に含水率と水分活性值は正比例する。 水分活性が 0.4 以上になると酵素が活性化するが11), そ のためには含水率が 7 ～ $8 \%$ 以上である必要がある（図 2 )。日本の茶生産は1970年代以降, 煎茶が大部分となり, 含水率や水分活性に大きな影響を与える乾燥に関する研 究も煎茶が主となった。今後, 紅茶を初めとして茶種が 多様化すれば, それぞれの茶種に最適な乾燥法や好まし い含水率を明らかにする必要がある。

今回供試した試料の中には含水率が $8 \%$ 以上のものも 多く, $12 \%$ 近いものも含まれたが, 水分活性は, ほとん どの試料が 0.6 前後以下, すべての試料が 0.7 以下で微生 物は繁殖できないレベルであった ${ }^{11)}$ 。したがって中国茶 の含水率が $12 \%$ 程度までは微生物が繁殖する心配はない と考えられる。中国茶は製造や流通の歴史が古く，長い 経験の中で適正な含水率の制御技術が蓄積されてきたと 


\section{考えられた。}

しかし，スリランカの研究機関で示した適正な含水 率は $3 \%$ で, $6 \%$ 以上では急速な品質の低下が起こり, $8 \%$ 以上では微生物が増殖するため, $7 \%$ 以上では再 加熱を推奨しているが21), 本試験の結果とは異なった。 Stagg（1974）が英国で，ケニアで製造した直後の茶を 空輸して行った試験では, $35^{\circ} \mathrm{C}$ の高温, 多湿条件下では 吸湿して含水率が $7 \%$ 以上になると, 脂質の分解やテア フラビンの酸化重合によってテアルビジンが増加し, 品 質が低下した。しかし，英国では室内の環境では密封し なくても, 含水率は $7 \%$ 以上には増加しなかった ${ }^{22)}$ 。ス リランカの基準 ${ }^{21)}$ は, 高温, 多湿の室内で吸湿を前提 とした基準で, 含水率が $8 \%$ で微生物が増殖するのでは なく, 乾燥時に $8 \%$ で, さらに吸湿した場合に微生物が 増殖する可能性があると考えられた。

含水率が同程度であっても，水分活性が大きく異なる 場合があったが, 生葉の硬化度, 製造法, 後熟, 製造後 の加湿などの要因が考えられるので, 今後検討が必要で ある。

\section{5 摘 要}

国内で生産される茶の種類が多様化した場合の適正な 含水率の知見を得るために，中国茶の含水率と水分活性 を測定した。また，中国及び台湾産の紅茶と他の産地の 紅茶の含水率及び水分活性の比較を行った。中国茶の茶 種間で含水率に差が認められた。白茶，黒茶の含水率は 青茶, 緑茶, 紅茶より高かった。中国産の紅茶の含水率 の平均值は $8.73 \%$ で，ネパール，インド，日本産の紅茶 の含水率より高かった。青茶は含水率のばらつきが大き かった。緑茶, 青茶, 紅茶, 黒茶においては茶の含水率 と水分活性の間に正の相関関係が認められ，含水率が高 いほど, 水分活性が高い傾向が認められた。黒茶は青茶, 白茶, 紅茶に比べて同程度の含水率の場合は水分活性が 低い傾向が認められた。ほとんどの中国茶の水分活性は 0.6 前後より低く, 含水率が $12 \%$ 程度までは微生物は繁 殖できないと考えられた。

\section{6 謝 辞}

数多くの多様な中国茶の材料を提供していただいた茶 学の会会長, 小泊重洋氏ならびに黒茶を提供していただ いた日本茶インストラクター, 早川博子氏, 現地で購入 した試料を提供していただいた森川亮一氏に深謝する。
その他に井村製茶, 錦園石部商店, (株)小栗農園, 井手暢 子氏, 有限会社tastea, 松永明子氏, 中山淑子氏, 鈴木 英之氏，佐藤安志氏，長田幸子博士，徳田志保氏，浦山 尚弥氏, 渡辺拓哉氏, 山本明香氏, 横山嗣人氏, 吉田建 実氏, 吉野亜湖氏にも試料を提供いただいた。ここに記 して謝意を表する。

\section{7 引用文献}

1 ) Japan Export Trade Promotion Agency (1958):Moisture Content. Japan Tea, p3.

2 )「茶」編集部（1950）：第四回全國製茶品評會審査成績表. 茶, 3 (10), 59-65.

3 )「茶」編集部（1951）：第 5 回全國製茶品評會審査成績表. 茶, 4 (10), 90-99.

4) 角川修 (2013)：乾燥. 森田明雄 - 増田修一 - 中村順行 - 角 川修・鈴木壯幸編，茶の機能と科学。朝倉書店, pp81。

5 ）池田奈実子（2014）：日本産及び外国産の紅茶の含水率．野菜 茶業研究所報告, No. 13，43-47.

6 ）日本食糧新聞 (2013)：胃心伝真=べにふうき。日本食糧新聞, 10805, 1 .

7 ）公益社団法人日本茶業中央会（2015）：緑茶の茶期別, 茶種別 価格の推移. 平成 27 年度茶関係資料, 公益社団法人日本茶業 中央会, pp39.

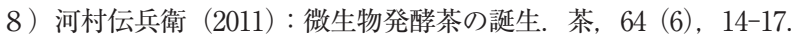

9 ) 公益社団法人日本茶業中央会 (2015) : 各種飲料の消費量の推移 平成 27 年度茶関係資料, 公益社団法人日本茶業中央会, pp54.

10）古谷弘三・原 利男 - 久保田悦郎 (1961）：煎茶の貯蔵条件が 品質に及ぼす影響について。茶研報，No. 18，42-46.

11) 中谷延二 (2011): 食品中の加工, 貯蔵, 調理に扔ける水. 食品学, 久保田紀久枝・森光康次郎編, 東京化学同人, pp23-24.

12）陳 橡 (1979）：茶葉分類的理論与実際. 安徽省茶業学会, 茶 業通報, $1 \cdot 2$ 合刊, 1-10.

13）原 利男（1990）：茶の水分の測定法. 茶研報，No. 87，85-92

14）柴田雄七（2006）：乾燥工程と荒茶. 機械製茶の理論と実際. 農文協, pp110-111.

15）徐 英祥 (2009): 揉捻. 台湾の茶，151-154, 日報印刷, 大阪.

16）池田奈実子（2013）：インド・スリランカ・ネパールのティーオ ークションサンプルの含水率. 日作紀, 82（別 2)，228-229.

17）坂本孝義（2014）：“本場の発酵茶”見聞録（1）～台湾にお ける紅茶生産〜。茶, 68 (1), 42-46.

18）坂本孝義（2014）：“本場の発酵茶” 見聞録（3）～中国江蘇 省に打ける紅茶生産〜。茶，68（3），26-29.

19）呂毅・郭雯飛・駱 少君・坂田完三（2004）：科学的審査法. 中国黒茶のすべて, 裳華房, pp108-110.

20) Samynathan, R. S., Palanisamy, C. P., Gandhi, S., Mandal, A. A., Padmanabham, M., Perisamy, S., and Kannisappan, V. (2015): Isolation and characterization of polyphenol oxidase from UPASI selected clone of Camellia sinensis (L.) O. Kuntze. Indo American Journal of Pharmaceutical Research, 5, 241-252.

21) Samaraweera, D.S.A.(2008): Dryer room operations. Handbook on Tea, Zoysa, A. K. N. Tea Research Institute of Sri Lanka, pp289-315.

22) Stagg, G. F. (1974): Chemical Changes Occurring during the Storage of Black Tea. J. Sci. Food Agric., 25, 1015-1034. 